\title{
Andrzej Ślusarz, Psychopedagogika rodziny księdza Piotra Poręby, Wydawnictwo UNUM, Kraków 2003, ss. 176
}

Zainteresowanie rodziną jest obecnie coraz większe. Jest to zrozumiałe, gdyż jeśli upada rodzina, to słabnie też całe społeczeństwo. Rodzina jest źródłem i kolebką mocnego i silnego państwa. Dlatego też ci, którzy chcą osłabić społeczeństwo, najpierw próbują osłabić rodzinę i godzą w nią. Zatem $\mathrm{z}$ tych między innymi powodów rodzina staje się niejako na nowo jednym z fundamentalnych wyzwań Kościoła i wysiłków duszpasterskich.

$\mathrm{W}$ ten nurtzainteresowania na nowo rodzinąi to we właściwym spojrzeniu na małżeństwo i rodzinę wpisuje się książka ks. Andrzeja Ślusarza Psychopedagogika rodziny księdza Piotra Poręby. Autor przedstawił w niej postać i dzieło na rzecz rodziny ks. prof. dr. hab. Piotra Poręby - założyciela na KUL-u w Lublinie w 1970 r. pierwszej w Polsce uniwersyteckiej katedry pedagogiki rodziny. Książka poświęcona jest w całości analizie twórczej pracy ks. prof. P. Poręby w kontekście psychopedagogiki rodziny i zawiera oryginalny oraz olbrzymi jego dorobek w zestawieniu z poglądami innych autorów, dokumentami Kościoła, a szczególnie nauczania papieża Jana Pawła II. W recenzowanej pozycji ks. A. Ślusarz przedstawił poglądy i dorobek naukowy ks. P. Poręby, wysunął główne nurty ujęcia przez niego pedagogiki rodziny, koncepcji małżeństwa i rodziny oraz wyjaśnił, na czym polega jej oryginalność.

Recenzowana publikacja składa się ze wstępu, czterech rozdziałów, zakończenia, trzech aneksów i bibliografii. We wstępie Autor wprowadził $\mathrm{w}$ poruszaną problematykę oraz postać ks. prof. P. Poręby. W rozdziale pierwszym: „Kierunki badań nad rodziną w Polsce po II wojnie światowej” zawarł przeprowadzone przez wybitnych specjalistów (jak np.: F. Adamski, J. Laskowski, L. Dyczewski, W. Piwowarski, T. Kukołowicz, M. BraunGałkowska, M. Ryśs badania nad rodziną w Polsce po II wojnie światowej na płaszczyźnie socjologicznej, psychologiczno-pedagogicznej i teologiczno-prawnej.

W rozdziale drugim: „Przygotowanie do małżeństwa według księdza Piotra Poręby” Autor podał nową koncepcję ks. P. Poręby spojrzenia na rodzinę i małżeństwo jako podstawowe środowisko miłości, akceptacji, bezpieczeństwa, miejsce budzenia i realizacji potrzeb człowieka zarówno rodzicielskich, jak 
wychowywania do określonych ról społecznych. Właściwa atmosfera jest zadatkiem szczęśliwego życia rodzinnego małżeństw i dzieci, które w przyszłości założą rodzinę. Najlepszym przygotowaniem do małżeństwa jest obserwacja i możliwość powielenia udanego małżeństwa rodziców. Wskazując cechy związku małżeńsko-rodzinnego: jedność, trwałość, nierozerwalność, podkreślił rolę rodziców jako wychowawców i potrzebę nieustannego ich dokształcania w duszpasterstwach rodzin. Wśród metod, które wymienił decydujące znaczenie obok atmosfery i dialogu mają te, które poparte są przykładem.

W rozdziale trzecim: „Czynniki warunkujące optymalny rozwój małżeństwa i rodziny według księdza Piotra Poręby" ks. A. Ślusarz, omawiając najdogodniejsze warunki rozwoju małżeństwa i rodziny, wskazał na metodę podmiotowego traktowania samych małżonków i członków rodziny, zwrócił uwagę na więź miłości małżonków, wspólne zainteresowania, charakter, światopogląd. Więź małżonków jest uwarunkowana nie tylko właściwościami wewnętrznymi, ale również zewnętrznymi - środowiskowymi, bytowymi, ekonomicznymi, mieszkaniowymi. Środki wychowania to rozwój i urobienie psychiczne, czyli celowe działania zmierzające do dokonania pewnych zmian u dzieci.

Natomiast w ostatnim, czwartym, rozdziale: „Próba oceny poglądów księdza Piotra Poręby w świetle ujęć współczesnych” Autor podjął się próby oceny - w kontekście dzisiejszych ujęć - publikacji ks. P. Poręby dotyczących takich dziedzin, jak: pedagogika, psychologia, socjologia, teologia. Ks. P. Poręba wyszedł jako pierwszy naprzeciw chrześcijańskim małżonkom $\mathrm{z}$ „teologią praktyczną". Autor starał się oceniać zawartość merytoryczną, oryginalność - pod względem treści i pod względem formy - i możliwość zastosowania praktycznego $\mathrm{w}$ duszpasterstwie $\mathrm{w}$ świetle Instrukcji Episkopatu Polski i IV synodu diecezji tarnowskiej.

W zakończeniu ks. A. Ślusarz podkreślił, że psychopedagogika w ujęciu ks. P. Poręby jest aktualna $\mathrm{w}$ dzisiejszych warunkach, gdyż każda rodzina ma nie tylko prawo, ale i obowiązek przygotować swe dzieci do przyszłych ról, a niestety często nie jest właściwie przygotowana do podjęcia tego zadania i oczekuje pomocy. Autor przedstawił także podsumowanie całej pracy oraz zaproponował postulaty i wnioski. Wartościowe są także trzy aneksy, w którym umieścił: życiorys ks. P. Poręby (aneks 1), charakterystykę jego pracy naukowej (aneks 2), a także wykaz tematów prac naukowych napisanych pod kierunkiem ks. prof. P. Poręby w ramach specjalizacji duszpasterstwa rodzin w latach 1968-1982: 71 prac magisterskich, 32 prac licencjackich, 15 prac doktorskich (aneks 3). Całość pracy kończy bibliografia, w której na szczególne podkreślenie zasługuje literatura podstawowa $\mathrm{z}$ publikacjami ks. P. Poręby. 
Wydaje się, że tak sformułowany tytuł książki jest mało precyzyjny, niejednoznaczny, gdyż może $\mathrm{z}$ niego także wynikać, iż chodzi o rodzinę ks. P. Poręby, a nie o jego myśl, nauczanie na temat rodziny. Koncepcja psychopedagogiki rodziny w ujęciu ks. P. Poręby trwa nadal, gdyż ks. profesor pozostawił po sobie wielu uczniów, naśladowców i kontynuatorów, a także olbrzymi dorobek. W omawianej pracy ks. A. Ślusarza została przedstawiona psychopedagogika rodziny, spojrzenie na małżeństwo i rodzinę $\mathrm{w}$ świetle publikacji ks. prof. P. Poręby. Z pewnością nie wyczerpuje ona w pełni tego bardzo złożonego zagadnienia, ale $\mathrm{z}$ pewnością pozwoli lepiej zrozumieć tę szeroką i złożoną problematykę, dlatego warto sięgnąć po tę pozycję. Przyszłość społeczeństwa, państwa zależy przecież od rodziny, dlatego ta pozycja może stać się jedną z przyczyn wzmożonej troski o szczęście i świętość małżeństwa i rodziny.

Ks. Józef Stala 